\title{
Infiltration-Exfiltration System for Stormwater Control: A Full Scale Test ${ }^{\dagger}$
}

\author{
Mariana Marchioni ${ }^{1}$, Gianfranco Becciu ${ }^{1}$ and Claudio Oliveira ${ }^{2, *}$ \\ 1 Politecnico di Milano, Department of Civil and Environmental Engineering (DICA), Piazza Leonardo da \\ Vinci 32, 20133 Milan, Italy; mariana.marchioni@polimi.it (M.M.); gianfranco.becciu@polimi.it (G.B.) \\ 2 Universidade São Judas Tadeu, Dipartment of Civil Engineer, R. Taquari, 546, São Paulo 03166-000, Brazil \\ * Correspondence: claudio.silva@abcp.org.br \\ + Presented at the 4th International Electronic Conference on Water Sciences, 13-29 November 2019; \\ Available online: https://ecws-4.sciforum.net/.
}

Published: 12 November 2019

\begin{abstract}
The current approach to stormwater management should focus on dealing with water on its source. The Sustainable Urban Drainage Systems (SuDS) promotes runoff peak flow and volume attenuation, load removal while providing amenites and biodiversities but can be difficult to apply in developed urban centers. An infiltration-exfiltration system (IES) placed on road gutters can function on receiving runoff from roads and directing them to the sewers system reducing peak flow and volume. This research follows up a full-scale test of an IES installed in São Paulo, Brazil. The IES has $49 \times 1880 \mathrm{~m}$ dimension and a cross-section of $49 \times 30 \mathrm{~cm}$ with a pervious concrete surface layer. The pervious concrete showed mechanical results acceptable for a low vehicular traffic and infiltration rate that allows water infiltration. Rainfall-runoff modeling showed that the proposed IES had a low effect on runoff peak flow and volume attenuation. A deeper gravel layers depth and outlet flow restrictor would improve performance. The proposed IES function on avoid ponding, promoting water treatment, and reducing inlet maintenance.
\end{abstract}

Keywords: stormwater management; SuDS; pervious concrete

\section{Introduction}

The traditional approach of stormwater management to collecting, conveying, and discharging runoff is becoming impractical in the current growing urbanization scenario and altered precipitation patterns, with high-intensity events being observed more frequently. The contaminants present on runoff after washing off surfaces are an important cause of river and stream pollution. To avoid saturation of the urban drainage system and improve water quality, current strategies for stormwater management act on water management in its source and encouraging systems that also function on water treatment. These systems are often referred to as SuDs (sustainable urban drainage systems), green infrastructures, BMPs (best management practices), LIDs (low impact developments). This approach is already mentioned in public policies on urban drainage and land use, especially by limiting the discharge and requiring detention or retention tanks [1].

The application of these strategies for stormwater control may be difficult, especially in fully developed urban areas. Retrofitting of such areas is usually more expensive and may be limited to few urban spaces. One of the more feasible and effective interventions is the change of traditional road, pavement, and parking surfaces for permeable ones.

However, these alterations are limited by the need to find a trade-off between good infiltration performance and sufficient strength to traffic loads. That is the reason for which this solution is often applied only to roads with low traffic loads. 
An alternative is to limit the adaptations to road gutters that are less stressed by dynamic loads. The use of an infiltration-exfiltration system as street gutters, consisting of a porous concrete surface with a gravel base, may achieve several goals. First, stormwater runoff to be discharged into the sewer network is reduced. Second, peaks of stormwater flow into the sewer network are reduced, due to the temporary storage inside the porous layers of the part of stormwater runoff that cannot be infiltrated. Third, the porous surface acts as a filter, promoting load removal from runoff. Previous research analyzed the IES performance on runoff peak flow and volume reduction [2] and on load removal [3].

\section{Material and Methods}

\subsection{Experimental Area}

An IES road gutter was installed in the headquarters of the Brazilian Portland Cement Association (ABCP) located in São Paulo, Brazil. The system has $49 \mathrm{~cm}$ width and $1880 \mathrm{~cm}$ length and a cross-section consisting of a $10 \mathrm{~cm}$ surface of pervious concrete and $20 \mathrm{~cm}$ of gravel over a natural soil subbase, without geotextile and is connected to an inlet PVC pipe (Figure 1).
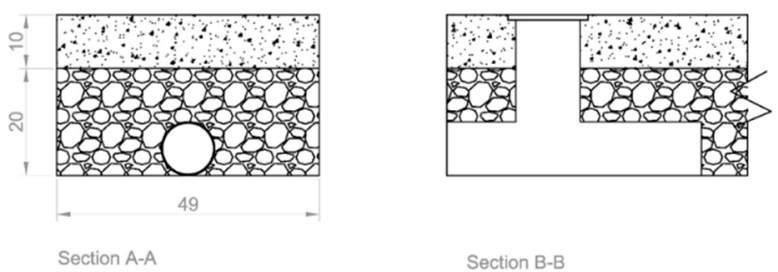

Section B-B

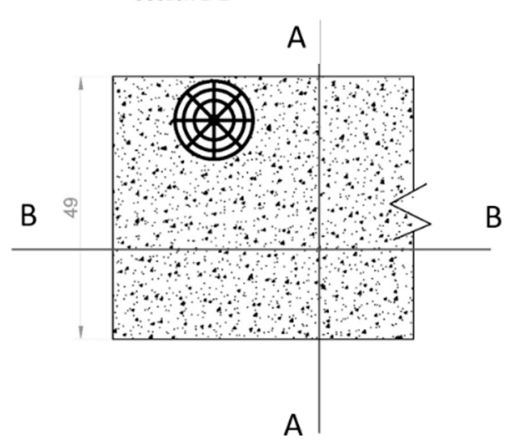

Figure 1. IES details: Plan view, section A-A (longitudinal section), and B-B (cross-section).

The IES was placed on the entrance road and received stormwater of 1626 square meters contribution area on half of the entrance road and two parking lots with hexagonal concrete blocks surface and two grass garden areas according Table 1 and Figure 2.

Table 1. Contribution areas and slope.

\begin{tabular}{ccc}
\hline Description & Area $\left[\mathbf{m}^{2}\right]$ & Slope $[\mathrm{m} / \mathbf{m}]$ \\
\hline Parking lot + garden & 1050 & 0.01 \\
\hline Parking lot & 365 & 0.01 \\
\hline Garden & 143 & 0.03 \\
\hline Main road (half) & 59 & 0.01 \\
\hline IES & 9 & 0.01 \\
\hline
\end{tabular}




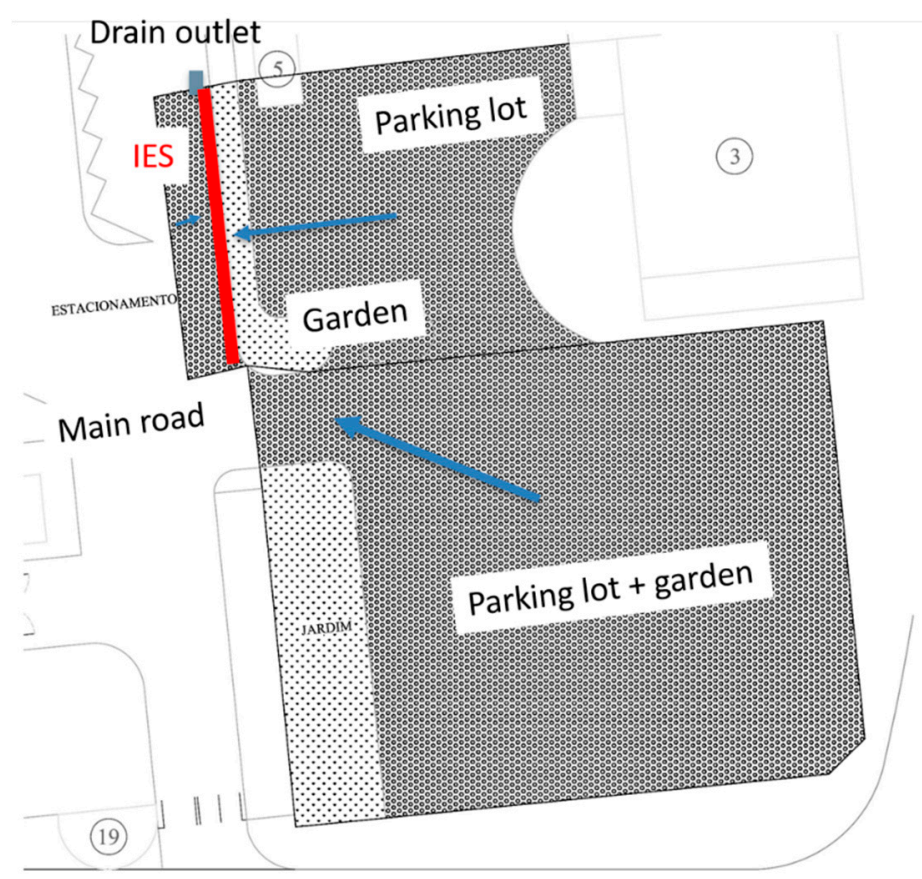

Figure 2. Experimental area.

The pervious concrete was placed over the gravel layer and compacted using a manual compaction hammer due to space restriction. It is important to notice that compaction can alter pervious concrete characteristics [4].

\subsection{Pervious Concrete Characteristics}

The pervious concrete surface consists of a mix design containing a cement type CP V Ari (high initial resistance), aggregates, and admixture. Specimens mold on laboratory were tested for compressive strength on a cylindric specimen (ABNT NBR 5739), flexural strength on a prismatic specimen, and diametral compressive strength. Samples extracted from the finished area were tested for water absorption, void content, and density.

\subsection{Infiltration Rate}

Permeability tests were held on the finish area using a falling head permeameter with a $30 \mathrm{~cm}$ diameter and a water head test level between 10 and $15 \mathrm{~mm}$, according to ABNT NBR 16,416. Details of the permeability test method can be found in [5]. The first test (2 October 2019) was held after a rainfall event carried particle load from the garden area towards the IES, visually clogging the system. Before the second measure (17 October 2019), the IES was cleaned by regular sweeping, and before the third test, (23 October 2019) with pressure water.

\subsection{Rainfall-Runoff Modelling}

The stormwater management model (SWMM) was used to simulate the rainfall-runoff transformation considering the previous scenario, before the IES installation, and after. The simulation used typical urban area subcatchments parameters. For the concrete block pavement area, a 0.01 Manning Number was used. For both garden areas, the Horton infiltration model with a minimum infiltration rate of $0.5 \mathrm{~mm} / \mathrm{h}$ was used. The depression storage was adopted as $0.05 \mathrm{~mm}$ for both pervious and impervious areas. For the IES simulation, the LID build-in function of SWMM was used considering a seepage rate of $0.3 \mathrm{~mm} / \mathrm{h}$, coherent with the low permeability soil typical of that area, and a drain placed on the lower part of the storage layer (gravel layer). For the simulations, Chicago-storm hyetograph obtained with the IDF (Intensity-Duration-Frequency) equation from 
IAG-USP was used [6]. With the rainfall-runoff simulations the outlet and subcatchments hydrograph were obtained for the pre and post retrofit scenario and the IES performance data.

\section{Results}

Results obtained for the pervious concrete characteristics, infiltration rate test on the IES surface, and the rainfall-runoff modeling results.

\subsection{Pervious Concrete Characteristics}

Laboratory samples molded with the proposed mix design presented the results gathered in Tables 2-4. Table 5 shows the results for water absorption, void content, and density from the samples extracted from the finished experimental area.

Table 2. Compressive strength on a cylindric specimen (ABNT NBR 5739).

\begin{tabular}{ccccccc}
\hline Specimen & Molded & Test & Age & \multicolumn{2}{c}{ Compressive Strength } \\
\hline & & & [days] & \multicolumn{3}{c}{ [MPa] } \\
\hline PC1 & 29-ago & 30-ago & 1 & 12.9 & \multirow{2}{*}{2.9} \\
PC2 & 29-ago & 30-ago & 1 & 12.2 & 21.3 \\
\hline PC3 & 29-ago & 02-set & 4 & 21.3 & \multirow{2}{*}{20.4} \\
\hline PC4 & 29-ago & 05-set & 7 & 19.9 & 20.8 \\
PC5 & 29-ago & 05-set & 7 & 20.4 & \multirow{2}{*}{20.8} \\
\hline PC6 & 29-ago & 12-set & 14 & 20.8 & \\
\hline PC7 & 29-ago & 26-set & 28 & 18.7 & \\
PC8 & 29-ago & 26-set & 28 & 20.8 &
\end{tabular}

Table 3. Flexural strength on a prismatic specimen.

\begin{tabular}{ccccc}
\hline Specimen & Molded & Test & Age & Flexural Strengths \\
\hline & & & {$[$ days] } & {$[\mathrm{MPa}]$} \\
\hline PC1 & 29-ago & 05-set & 7 & 2.15 \\
\hline PC2 & 29-ago & 05-set & 7 & 1.87 \\
\hline PC3 & 29-ago & 12-set & 14 & 2.3 \\
\hline PC4 & 29-ago & 12-set & 14 & 2.09 \\
\hline PC5 & 29-ago & 26-set & 28 & 2.42 \\
\hline PC6 & 29-ago & 26-set & 28 & 2.45 \\
\hline
\end{tabular}

Table 4. Diametral compressive strength.

\begin{tabular}{ccccc}
\hline Specimen & Molded & Test & Age & Diametral Compressive Strength \\
\hline & & & [days] & {$[\mathrm{MPa}]$} \\
\hline PC1 & 29-ago & 26-set & 28 & 2.17 \\
\hline PC2 & 29-ago & 26-set & 28 & 2.47 \\
\hline
\end{tabular}

Table 5. Water absorption, void content, and density for extracted samples.

\begin{tabular}{ccc}
\hline Item & Unit & Value \\
\hline Water absorption & $\%$ & 6.35 \\
\hline Void content $^{(1)}$ & $\%$ & 14.3 \\
\hline Density $^{(1)}$ & $\mathrm{g} / \mathrm{cm}^{3}$ & 2.64 \\
\hline
\end{tabular}

(1) Ms/(Ms-Mi) Ms: dry mass (g) Mi: mass after boiling (g). 


\subsection{Infiltration Rate}

The infiltration rate results are gathered in Table 6 . The infiltration rate obtained on 2 October 2019 preceded from a rainfall event that clogged the IES surface with soil particles load, however, the obtained rate is still enough to allow water infiltration. Before the second test (17 October 2019), the IES was cleaned by regular sweeping, presenting an increase in infiltration rate. The IES was then cleaned with pressure water achieving an infiltration rate of $17,786 \mathrm{~mm} / \mathrm{h}$.

Table 6. Infiltrate rate obtained with an in situ falling head permeameter.

\begin{tabular}{ccc}
\hline Test Date & \multicolumn{3}{c}{ Infiltration Rate } \\
\hline & {$[\mathrm{m} / \mathrm{s}]$} & {$[\mathrm{mm} / \mathrm{h}]$} \\
\hline $02 / 10 / 2019$ & $6.00 \times 10^{-4}$ & 2174 \\
\hline $17 / 10 / 2019$ & $1.60 \times 10^{-3}$ & 5767 \\
\hline $23 / 10 / 2019$ & $4.90 \times 10^{-3}$ & 17,786 \\
\hline
\end{tabular}

\subsection{Rainfall-Runoff Modelling}

The rainfall-runoff simulation allowed to obtain the runoff peak flow, total runoff volume, and the hydrograph from the outlet, IES and subcatchments for the pre and post-retrofit scenarios (Tables 7-9, Figures 3 and 4).

Table 7. Pre-retrofit runoff peak flow and total volume.

\begin{tabular}{cccccc}
\hline & Description & Area & Discharge & Peak Flow & Total Volume \\
\hline & {$[-]$} & {$\left[\mathrm{m}^{2}\right]$} & {$[-]$} & {$[\mathrm{L} / \mathrm{s}]$} & {$[$ liters $]$} \\
\hline OUTLET & - & & - & 77.57 & 92 \\
\hline S1 & Garden & 143 & S3 & 2.63 & 3 \\
\hline S2 & Parking lot & 365 & S3 & 16.04 & 22 \\
\hline S3 & Main road (half) & 68 & OUTLET & 77.67 & 92 \\
\hline S4 & Parking lot + garden & 1050 & S3 & 56.98 & 64 \\
\hline
\end{tabular}

Table 8. Post-retrofit runoff peak flow and total volume.

\begin{tabular}{cccccc}
\hline & Description & Area & Discharge & Peak Flow & Total Volume \\
\hline & {$[-]$} & {$\left[\mathrm{m}^{2}\right]$} & {$[-]$} & {$[\mathrm{l} / \mathrm{s}]$} & {$[1]$} \\
\hline OUTLET & - & - & - & 78.33 & 92 \\
\hline S1 & Garden & 143 & IES & 2.63 & 3 \\
\hline S2 & Parking lot & 365 & IES & 16.04 & 22 \\
\hline S3 & Main road (half) & 59 & IES & 3.24 & 4 \\
\hline S4 & Parking lot + garden & 1050 & IES & 56.98 & 64 \\
\hline IES & IES (drain) & 9 & OUTLET & 79.16 & 92 \\
\hline
\end{tabular}

Table 9. IES performance.

\begin{tabular}{ccc}
\hline Item & Unit & Value \\
\hline Total inflow & {$[\mathrm{mm}]$} & 10,243 \\
\hline Infiltration loss & {$[\mathrm{mm}]$} & 1 \\
\hline Surface outflow & {$[\mathrm{mm}]$} & 6959 \\
\hline Drain outflow & {$[\mathrm{mm}]$} & 3262 \\
\hline Initial storage & {$[\mathrm{mm}]$} & 0 \\
\hline final storage & {$[\mathrm{mm}]$} & 21 \\
\hline
\end{tabular}




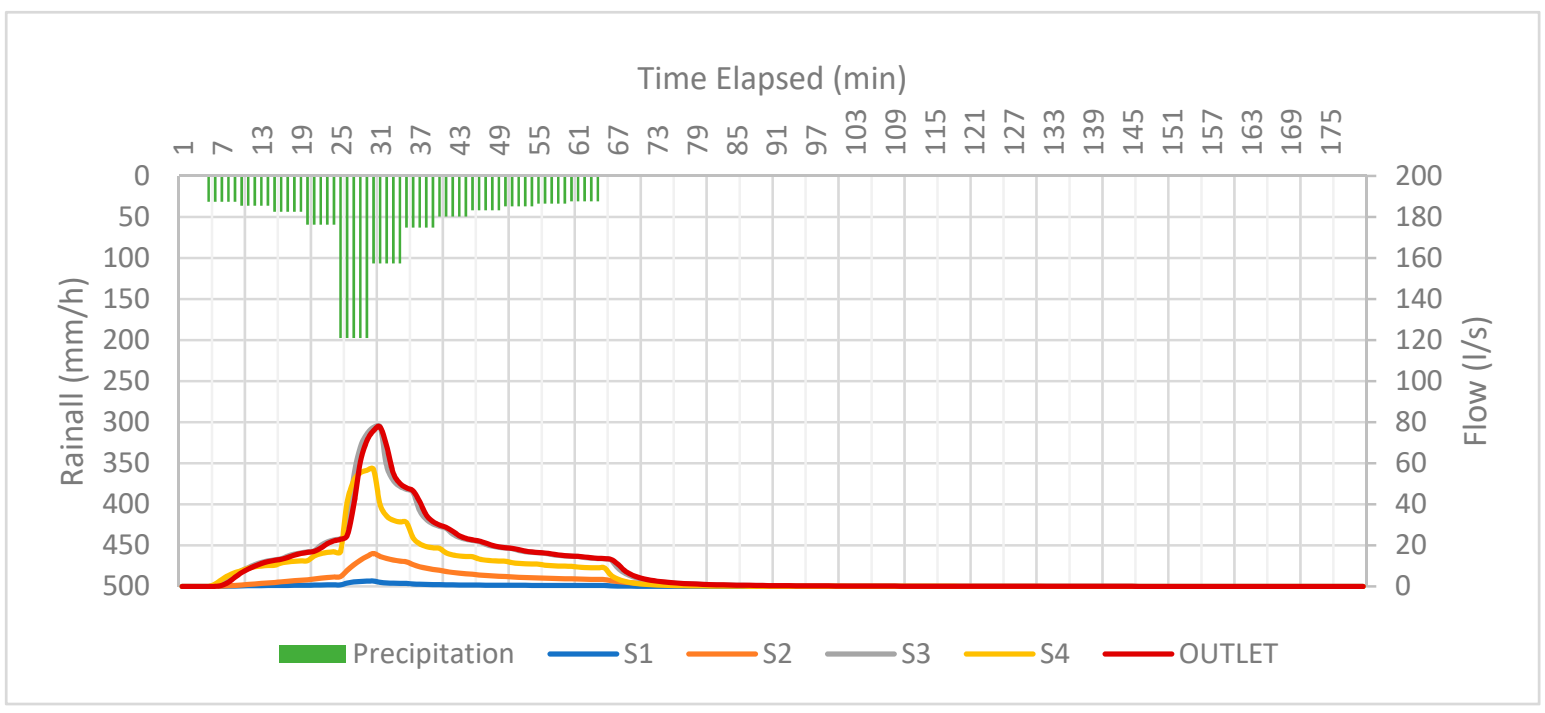

Figure 3. Pre-retrofit hydrograph.

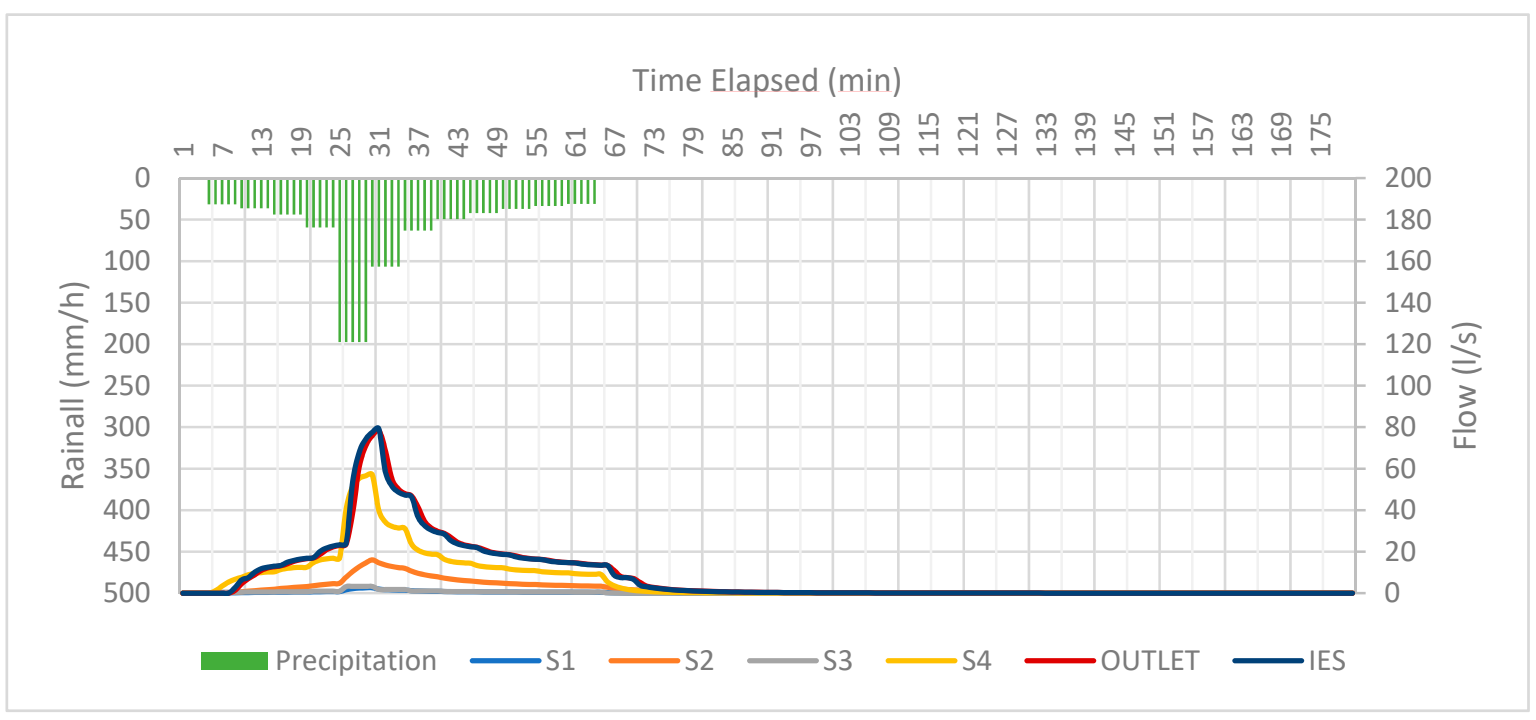

Figure 4. Post-retrofit hydrograph.

\section{Discussion}

An infiltration-exfiltration system with $18.8 \mathrm{~m}$ length and $0.49 \mathrm{~m}$ width was built to receive rainfall from a $1617 \mathrm{~m}^{2}$ contribution area. The IES is on a pervious concrete layer $(10 \mathrm{~cm})$ and gravel layer $(20 \mathrm{~cm})$ and is connected to the drainage system through a $10 \mathrm{~cm}$ diameter PVC pipe. The pervious concrete layer presented a $20.8 \mathrm{MPa}$ compressive strength, $2.43 \mathrm{MPa}$ (average) flexural strength, and $2.32 \mathrm{MPa}$ diametral compressive strength for 28 days age and laboratory molded specimens. Samples extracted presented $14.3 \%$ of void content. The IES infiltration rate was measured after a rainfall event, presenting a $2174 \mathrm{~mm} / \mathrm{h}$. After cleaning with pressure water, the infiltration rate raised to $17,786 \mathrm{~mm} / \mathrm{h}$. Rainfall-runoff simulation for the proposed IED did not register peak flow and volume reduction comparing pre and post-retrofit.

\section{Conclusions}

The current urbanization scenario demands a shift in stormwater management, favoring onsource solutions and encouraging reuse, infiltration, and temporary storage. These solutions are often referred to as SuDs (Sustainable Urban Drainage Systems) and provide runoff peak flow and volume attenuation while delivering amenities and biodiversity opportunities. However, it may be difficult 
to apply these systems in a fully urbanized environment requiring solutions that may be applied in a public space. The infiltration-exfiltration system placed in road gutters functions by reducing runoff peak flow and volume, avoiding ponding on gutters, and reducing drainage inlet maintenance. Previous research confirmed the performance of such systems.

An IES was built in the ABCP headquarters, in Brazil. The surface layer presented a high infiltration rate that allows stormwater infiltration. The pervious concrete characteristics were coherent with the low traffic vehicular use. The rainfall-runoff simulation did not show a reduction in peak flow and volume as expected. Considering the results, to improve IES performance on runoff peak flow and volume reduction, a deeper depth on the gravel layers and a flow restriction on the outlet tube would be necessary to facilitate storage. To facilitate infiltration, the outlet pipe could be placed in an offset position from the gravel layer and the system could also be combined with soakaways. The experimental area is going to be monitored to obtain data to calibrate and validate the rainfall-runoff model and to obtain load particle removal efficiency.

Author Contributions: C.O. conceived, designed, and follow up the experiments, M.M. contributed with the rainfall-runoff modelling and wrote the paper, G.B. analyzed the data. All authors have read and agreed to the published version of the manuscript.

Acknowledgments: The authors appreciate the contribution of RE9 Soluções Ecológicas and Polimix on funding the full-scale test and the $\mathrm{ABCP}$ on providing the space.

Conflicts of Interest: The authors declare no conflict of interest.

\section{Abbreviations}

The following abbreviations are used in this manuscript:

ABCP Brazilian Portland Cement Association

IDF Intensity-Duration-Frequency

IES infiltration-exfiltrarion system

\section{References}

1. Marchioni, M.L.; Becciu, G. Permeable Pavement Used on Sustainable Drainage Systems (SUDs): A Synthetic Review of Recent Literature; WIT Press Urban Water II: Southampton, UK. 2014; p. 12.

2. Marchioni, M.; Becciu, G. Infiltration-exfiltration system for stormwater runoff volume and peak attenuation. Int. J. Saf. Secur. Eng. Southampton, United Kingdom. 2018, 8, 473-483.

3. Teng, Z.; Sansalone, J. In situ partial exfiltration of rainfall runoff. II: Particle separation. J. Environ. Eng. 2004, 130, 1008-1020.

4. Brugin, M.; Marchioni, M.; Becciu, G.; Giustozzi, F.; Toraldo, E.; Andrés-Valeri, V.C. Clogging potential evaluation of porous mixture surfaces used in permeable pavement systems. Eur. J. Environ. Civ. Eng. 2020, 24, 620-630.

5. Marchioni, M.; Becciu, G.; Silva, C. Critical Analysis of the Brazilian National Standard for Concrete Permeable Pavement. WIT Trans. Ecol. Environ. 2015, 192, 443-453.

6. Júnior, F.M.; Magni, N.L.G. Equações de chuvas intensas do Estado de São Paulo. Governo do Estado de São Paulo-Secretaria de Recursos Hídricos, Saneamento E Obras-Departamento de Águas E Energia ElétricaCentro Tecnológico de Hidráulica E Recursos Hídricos: São Paulo, Brazil. 1999.

(C) 2019 by the authors. Licensee MDPI, Basel, Switzerland. This article is an open access article distributed under the terms and conditions of the Creative Commons Attribution (CC BY) license (http://creativecommons.org/licenses/by/4.0/). 